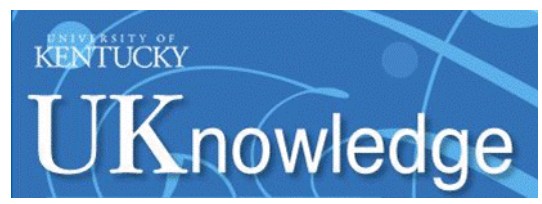

University of Kentucky

UKnowledge

4-2002

\title{
Effectiveness of Current Therapy of Bacterial Vaginosis
}

Petya M Andreeva

State University Hospital of Obstetrics and Gynecology "Maychin Dom", Bulgaria

Hatim A. Omar

University of Kentucky, hatim.omar@uky.edu

Follow this and additional works at: https://uknowledge.uky.edu/pediatrics_facpub

Part of the Pediatrics Commons

Right click to open a feedback form in a new tab to let us know how this document benefits you.

\section{Repository Citation}

Andreeva, Petya M and Omar, Hatim A., "Effectiveness of Current Therapy of Bacterial Vaginosis" (2002). Pediatrics Faculty Publications. 85.

https://uknowledge.uky.edu/pediatrics_facpub/85

This Article is brought to you for free and open access by the Pediatrics at UKnowledge. It has been accepted for inclusion in Pediatrics Faculty Publications by an authorized administrator of UKnowledge. For more information, please contact UKnowledge@lsv.uky.edu. 


\section{Effectiveness of Current Therapy of Bacterial Vaginosis}

Digital Object Identifier (DOI)

http://dx.doi.org/10.1515/IJAMH.2002.14.2.145

\section{Notes/Citation Information}

Published in International Journal of Adolescent Medicine and Health, v. 14, no. 2, p. 145-148.

(c) Freund Publishing House Ltd.

The copyright holder has granted permission for posting the article here. 


\title{
Effectiveness of current therapy of bacterial vaginosis
}

\author{
Petya M Andreeva, MD and Hatim A Omar, MD
}

Sexually Transmitted Diseases Center, State University Hospital of Obstetrics and Gynecology "Maychin Dom", Sofia, Bulgaria and Department of Pediatrics,
University of Kentucky, Lexington, United States of America

Abstract: The study was conducted in order to evaluate effectiveness of the treatment of bacterial vaginosis (BV) with different therapeutic regimes according to recommendations of the World Health Organization (WHO). During a one-year period (February 2000-February 2001) the Sexually Transmitted Diseases (STD) Center was visited by 482 women aged 14-51. The diagnosis of BV was established by standard methods: Amsel's clinical criteria and Gram stain of vaginal discharge. The first-line treatment was oral Metronidazole $2 \mathrm{~g}$ single dose. Second line was Metronidazole $500 \mathrm{mg}$ twice daily orally for 7 days or oral Clindamycin $300 \mathrm{mg}$ twice daily for seven days. BV was confirmed in 74 women (15.4\%). Most often it was observed in women aged 17-30 years of age. Thirty-three ( $44.6 \%$ of total) were young women $14-21$ years of age. Thirty-one (42\%) women received a follow-up examination and of those, 11 (38.7\%) needed a repeat treatment for BV due to unsatisfactory results of this treatment. It is concluded that treatment of BV with standard methods was not always effective with no significant difference between women under 21 years and older women found in regards to response to treatment. Besides antibiotic treatment, the so-called Probiotics (Lactobacillus acidophilus) can be taken into consideration as an alternative treatment. Additional research about the therapeutic effect of this type of drugs is needed.

Kegwords: Bacterial vaginosis, vaginitis, Gardnerella Vaginalis, Probiotics

Correspondence: Hatim Omar, MD, Associate Professor, Director of Adolescent Medicine and Young Parent programs, J422, Kentucky Clinic, University of Kentucky, Lexington, KY 40536-0284, United States. Tel: 859-323-6426 ext. 307, Fax. 859-257-7706, E-mail: haomar2@pop.uky.edu

Submimed: October 22, 2001. Revised: January 11, 2002. Accepted: January 18, 2002.

\section{INTRODUCTION}

Bacterial vaginosis (BV) is one of the most common infections of the lower genital tract in women. This condition can be characterised by a decrease or elimination of $\mathrm{H}_{2} \mathrm{O}_{2}$-producing lactobacilli and an overgrowth of mixed vaginal flora of aerobic, anaerobic and micro-aerophilic species (Gardnerella vaginalis, Mobiluncus, Bacteroides, Prevotella, Mycoplasma) in very large numbers. BV is connected with an increased risk of developing a number of gynecologic and obstetric complications such as premature delivery, premature rupture of amniotic membranes, and pelvic inflammations. Recently, BV has been found to promote HIV transmission and the advent of cervical cancer. The cause of the appearance of this disorder is unknown. As a result, the disease cannot be prevented $(1,2)$.

\section{MATERIAL AND METHODS}

Patients who took part in the study came to the Sexually Transmitted Diseases Center of the University Hospital of Obstetrics and Gynaecology "Maychin Dom". The study was conducted between February 2000 February 2001 with 482 women examined. The study includes an interview (history), a gynecological examination, and a microbiological evaluation. A file was created for every visitor to the center, including identification number, age, 
number of visits, previous sexually transmitted diseases (STDs) and if she belonged to a risk group (sexual workers, homosexual, homeless, intravenous drug users).

The gynecological examination included a speculum survey and an evaluation of the vaginal discharge - quantity, smell, color, and presence of purulent discharge from the cervix. The acidity of the vagina was measured with a pH-paper (Merck ${ }^{\circledR}$ ). Using a cotton stick, a sample was taken from the lateral vaginal wall and spread onto separate slides. On the first slide the vaginal secretions were mixed with $10 \%$ $\mathrm{KOH}$ to perform the amine test, on the second one - with one drop of saline to make a wet mount. The third smear was fixed on a spirit-lamp and Gram-stained. The preparations were then investigated under a light microscope with a magnification of 400 and for the colour smear using an immersion technique and a magnification of 1000 . A score system for evaluation of the risk of developing cervicitis was applied to patients with vaginal discharge (Table 1 ). If the score was two points or more these patients were at high risk (for gonococci and chlamydia Trachomatis infection) and a therapeutic scheme was applied.

Table 1. Risk score in patients with vaginal discharge. Patients with 2 or more points are considered high risk for cervicitis

Symptomatic partner 2 pts.
(urethral discharge)

- No constant partner 1 pt. and/or age under 20 years

- More then one partner 1 pt. during the last 3 months - New partner during the $1 \mathrm{pt}$.
last 3 months
The diagnosis of bacterial vaginosis was based upon Amsel's clinical criteria and the results of Gram's staining according to Nugent's score. The drugs Metronidazole and Clindamycine orally were used in patients having BV according to the therapeutic regimes described in Table 2. An alternative regime was used in cases of failure of treatment with Metronidazole $2 \mathrm{~g}$, cases of allergy to the drug. Clindamycine was the drug of choice in pregnant women.

Table 2. Therapeutic regimes used in treatment of $B V$.

\begin{tabular}{ll}
\hline First drug of choice & Altemative regimes \\
Metronidazole & Metronidazole 500 \\
$2 \mathrm{~g} /$ single dose, & mg twice daily for \\
orally & 7 days, orally \\
& $\begin{array}{l}\text { Clindamycin } 300 \\
\text { mg twice daily for }\end{array}$ \\
& 7 days, orally \\
\hline
\end{tabular}

\section{RESULTS}

Out of 482 women, the diagnosis of bacterial vaginosis was made in $15.4 \%$ (74 women). Thirty-three patients $(46.6 \%)$ were under 21 years of age. Twenty three percent ( 17 women, 8 under 2 lyears and 9 over 21 years of age) of the patients with BV had high-risk sexual behaviour. In $30.0 \%$ (22 women) BV co-existed with other sexually transmitted diseases - (Trichomoniasis, Condylomata Acuminata, Syphilis, Gonorhea). Pelvic inflammatory disease was diagnosed in one case. Thirty-one (42\%) patients returned to the Center for a followup examination within three weeks of the initial visit. In $19(61.3 \%)$ of these cases a normalization of the vaginal $\mathrm{pH}$ and a healing according to Amsel's and Nugent's criteria were established. (Table 3). No statistically significant difference was 
found between women under 21 and those older than 21 years. In $12(38.7 \%)$ patients, a repeat treatment for $\mathrm{BV}$ was needed

because of unsatisfactory results of this treatment.

Table 3. Effect of treatment in the different age groups.

\begin{tabular}{llll}
\hline $\begin{array}{l}\text { Efrect of the } \\
\text { treatment }\end{array}$ & $\begin{array}{l}\text { women up to 21 years } \\
n=15\end{array}$ & $\begin{array}{l}\text { women over 21 years } \\
n=16\end{array}$ & $\begin{array}{l}\text { All women with } \\
\text { follow-up } \\
n=31\end{array}$ \\
$\begin{array}{l}\text { Good response of the } \\
\text { treatment }\end{array}$ & $9(56.3 \%)$ & $19(61.3 \%)$ \\
$\begin{array}{l}\text { Unsatisfactory result } \\
\text { of the treatment }\end{array}$ & $5(33.4 \%)$ & $7(43.8 \%)$ & $12(38.7 \%)$
\end{tabular}

Table 4. Sexual transmission of $B V$.

FOR:

1. Discovery of G. vaginalis in the urethra

2. Correlation with the number of sexual partners 30 days before the examination.

3. Diminishing of the frequency of BV in monogamy couples

4. Lack of BV in virgin girls

AGAINST:

1. Bacteria do not persist in the male urethra.

2. The risk of BV does not grow with the number of sexual partners.

3. The frequency of relapse does not diminish after treatment of the partner.

4. Discovery of BV in virgin girls

5. The rectum of women is a reservoir for the microorganisms, associated with BV

\section{DISCUSSION}

Bacterial vaginosis (BV) is one of the most widespread vaginal infections and second in frequency in Europe, preceded only by vaginal candidomycosis. Incidence is reported to be anywhere from $4 \%$ to $64 \%$ (3). In our study the incidence of BV in our patient population was $15.4 \%$. There are many studies of the epidemiology of BV that shows a connection to sexual activity, a prior existing trichomoniasis or other sexually transmitted diseases, the use of contraceptives and in particular the use of intrauterine devices as well as black ethnic groups (4). Whether BV is a sexually transmitted disease is still an open question. In the present study $23 \%$ of the women with BV had high-risk sexual behaviour and in $31.1 \%$ the disease was combined with other STDs. There are many pros and cons for the classification of $\mathrm{BV}$ as a typical STD. (Table 4). The modem concept is that BV has the epidemiology of an STD, but it cannot be included in the list of the typical STDs (5). The results of treatment in the present study showed treatment failure in $38.7 \%$ of the cases (Table 3). Different studies show an 
effectiveness of Metronidazole and Clindamycin therapy ranging from $65 \%$ to $99 \%$, but this is only a short-term result (6). Although antibiotic therapy has been shown to eliminate BV-associated organisms, there is an extremely high recurrence rate, with reports up to $50 \%$ of patients experiencing recurrent infections $(\mathbf{7 , 8 )}$. The described therapeutic regimens are not sufficiently effective and new treatments need to be considered.

Evidence points towards recurrence occurring as a result of failure to establish a normal flora following antimicrobial therapy. Lactobacilli are a major component of normal vaginal microflora. They colonize the epithelium and form a defensive biofilm, due to their ability to form lactic acid, hydrogen peroxide, bacteriocins, Acidophylin, and other antimicrobial substances (9). Parent and other investigators report evidence of good therapeutic effect after administration of Lactobacillus acidophilus for treatment of BV $(10,11)$. The application of novel molecular methods in combination with appropriate biological tests give the opportunity to find specific strains that confer effect and exhibit immunoadjuvant properties (7). The study of natural bacteriocinogenic activity and Probiotics potential of newly isolated vaginal $\mathrm{LAB}$ is a condition to develop new preparations for clinical application. Additional studies of the therapeutic effect of this type of drugs are needed.

\section{REFERENCES}

1. Thorsen P, Jensen P, Jeune B et al: Few microorganisms associated with bacterial vaginosis may constitute the pathologic core: A population-based microbiologic study among 3596 pregnant women. Am J Obstet Gynecol 1998;178:580-7.

2. Hillier S, Krohn M, Rabe L et al: The normal vaginal flora, $\mathrm{H}_{2} \mathrm{O}_{2}$-produsing Lactobacilli and bacterial vaginosis in pregnant women. Clin Infect Dis 1993; 16(Suppl 4):S273-81.

3. Thomason JL, Gelbart SM, Scaglione NJ. Bacterial vaginosis: current review with indications for asymptomatic therapy. Am J Obstet Gyn 1991;165: 1210-7.

4. Kent HL. Epidemiology of vaginitis. Am J Obstet Gyn 1991; 165:1168-76.

5. Bump RC, Zuspan FP, Bueschling WJ III, et al.: The prevalence, six month persistence and predictive values of laboratory indicators of bacterial vaginosis (nonspecific vaginitis) in asymptomatic women. Am J Obstet Gyn 1984;150:917-24.

6. Joesoef M, Schmid G: Bacterial vaginosis: Review of treatment options and potential clinical indications for therapy. Clin Infect Dis 1995; 20(Suppl 1):S72-9.

7. McLean N, Rosenstein I: Characterisation and selection of a Lactobacillus species to re-colonise the vagina of women with recurent bacterial vaginosis. J Med.Microbiol 2000;49:54352.

8. Rosenstain I: Bacterial vaginosis and the normal vaginal flora: a dynamic relationship. Clin Lab 1998;44: 949 55.

9. Elmer G, Surawicz C, McFarland L: Biotherapeutic agents. A neglected modality for the treatment and prevention of selected intestinal and vaginal infections. JAMA 1996; 275: 870-6.

10. Parent $D$, Bossens $M$, Bayot $D$ et al.:Therapy of bacterial vaginosis using xogenously-applied Lactobacilli acidophili and a low dose of estriol. Arzneim Forsch Drug Res 1996; 46(1):68-73.

11. Reid G: Probiotic agents to protect the urogenital tract ageinst infection. Am J Clin Nutr 2001;73(2Suppl):437S-43. 